\title{
Child Safeguarding Practices in Light of the Deserving/Undeserving Paradigm: A Historical \& Contemporary Analysis
}

\author{
Wendy Sims-Schouten, A. Skinner \& K. S. J. Rivett
}

\begin{abstract}
Background:

Contemporary child protection systems in the UK need to be seen in light of the late nineteenth century child rescue movement, at a time of curbs in public spending, shifts in attitudes towards children's welfare and the development of social work. There are similarities in the social, institutional and legal contexts, between the nineteenth century and today, centralising 'deservedness', that determined and determines children's access to services.
\end{abstract}

Objective:

The current article compares historical data and practices of children in care in the UK, encompassing 1881-1918, with contemporary data and practices, through the lens of the deserving/undeserving paradigm, inherited from the Poor Law of 1834.

Participants and Setting:

Drawing on two data sets, namely historic children's case files $(\mathrm{N}=108), 1881-1918$ from the Children's Society (a philanthropic institution) highlighting the perception of custodians, doctors, professionals, as well as children and parents, and current data from interviews with young care leavers and safeguarding practitioners $(\mathrm{N}=42)$, our research focuses on the most disadvantaged children with complex needs and damaging (pre)care experiences.

Methods:

Data is analysed using thematic content analysis, framed within critical realist ontology, taking account of stratified non-linear dynamics of processes at different levels.

Results and Conclusion:

In both data sets the inability to support certain children is justified by referring to their complex needs and mental health and behavioural problems., Here, the child is held accountable and placed in the 'undeserving' category and consequently misses out on help and support, highlighting a need for awareness, and reflective and reflexive practice among practitioners/professionals.

\section{Introduction}


The starting point for this research is the notion that many of the issues that concern contemporary practices regarding child safeguarding and child protection have a historical trajectory that inform the present (see also Cradock, 2014; Hacking, 1991; Skinner \& Thomas, 2017). While there are a great many studies with a focus on child abuse and child welfare, either with a slant on historic practices (e.g. Delap, 2015; Gingell, 2001; Stewart, 2011 ) or contemporary practices (e.g. Bouma et al., 2018; Hood, 2016; Letourneau et al., 2018), there are no studies we are aware of which compare past and current practices and related conceptualisations simultaneously. The current article is novel in that it compares historical data and practices of children in care in the UK, encompassing 1881-1918, with contemporary data and practices, through the punitive lens of the deserving/undeserving paradigm, instigated (in theory and practice) by the New Poor Law of 1834. Our research focuses on the group of young people referred to by Stein (2006) as 'victims', a term used for the most disadvantaged children who have spent time in care, have complex needs and have had the most damaging pre-care family experiences. Their time in care is characterised by further difficulties, instability and disruption; after leaving care they are likely to be unemployed and to become homeless, to be lonely and isolated and have mental health problems (Hood, 2016; Stein, 2006).

Contemporary child protection systems in the UK need to be seen in light of beliefs and practices inherited from the nineteenth century child rescue movement and the development of social work. From the second half of the nineteenth century, child safeguarding in the UK was organised through a combination of state support and philanthropic voluntary agencies; one example of a voluntary organisation was the Waifs and Strays Society (currently known as the Children's Society) established in 1881 by Edward Rudolph (Skinner \& Thomas, 2017). State support for children was governed by the New Poor Law 1834, which also included (if necessary) admitting children to a workhouse (Crompton, 1997). Yet, whilst 
child philanthropy developed, providing child care services as an alternative to the workhouse, Government welfare policy was focused on separating the 'deserving' from the 'undeserving', encouraging self-help and changing behaviour (Skinner \& Thomas, 2017). During the latter decades of the nineteenth century, the Government cut back on public spending, restricting support in the community, with the intention to offer relief in the workhouse only. The Charity Organization Society, (COS) established in 1869, shared the views of the Government, worked with the Poor Law authorities and developed a system of personal social work (Lewis 1995, Hurren, 2015; Thane, 2012). Thus, the growth of child philanthropy coincided with a shift in cost-cutting, which could be seen as foundational to the social work that grew from it and, perhaps, even as an early example of the state outsourcing care of children to private interests.

Parental rights and state interference was contentious with regard to child welfare legislation. Additionally, conflicting attitudes to childhood whereby the child was either romanticized, or demonized, provided opportunities for inconsistencies in child welfare (Burnham, 2011; Cox, 2013). Regardless of these factors, the shift in social policy from laissez-faire to social control over childhood underpinned childcare legislation (Donzelot, 1997; Hendrick, 1997). The link between poverty and moral and individual failure was a primary concern for the philanthropic rescue agencies, in particular for the COS, who are seen as the early pioneers of social work. Their casework approach was based on investigative methods to ascertain the cause of poverty not the effect; and considered immediate material relief would not solve the problem long term (Author, 2017). Lifestyles of deserted wives were under scrutiny to ensure they were not considered to be 'irresponsible' or 'immoral' (Levine-Clark, 2010). Disapproval of lifestyles could result in the withdrawal of COS help which could force the family into desperate circumstances and dependent on the state; children rescued for child protection reasons such as neglect, or abuse and committed to care, could be caught up in the juvenile justice system and therefore criminalized (Cox, 2013). 
A coordinated strategy towards child safeguarding was not formulated until the latter half of the $20^{\text {th }}$ century and until then, child abuse and neglect were the province of public and private agencies (Gingell, 2001). Child support with a focus on mental health and wellbeing was influenced by the development of Child Guidance clinics from the early 1900s in the USA and the 1930s in the UK, consisting of members of three professions, namely psychiatry, psychology and psychiatric social work (Polat, 2016; Stewart, 2015). The focus was very much on parenting, interpersonal relationships and emotional disturbance and issues such as 'maladjustment' and 'truancy' were located in family dysfunction and perceived as outward manifestations of inner psychological processes (Sohasky, 2015). The institutions of Britain's welfare state were consolidated in the aftermath of the second world war, culminating with the establishment of the NHS (National Health Service) in 1948. A core component was free universal access to health services. Over the years various economic crises have mounted sustained attacks on collective welfare, introducing charges and market criteria into these (Sales, 2002). Currently, traditional goals of social justice and collective responsibility for public services have been abandoned in favour of individual achievement and neoliberalism (Harvey, 2007). This focus on individual accountability and responsibility strongly resembles the 'deserving/undeserving' criteria, introduced by the New Poor Law in 1834.

There is evidence that at present and in the past, certain children miss out on support and interventions due to complex needs, financial cuts, and ever changing thresholds (e.g. see Beito, 2011; Fong et al, 2018; Morrison, 2016; Rivett \& Kelly, 2016). Yet, underlying causal factors, material (such as budget cuts), and institutional (such as disconnections/fragmentation in the system) are all too often ignored here in favour of a focus 
on 'deservedness'. This can for example, be seen in the initial response to the sexual exploitation scandals in different cities in the UK (Rotherham, Derby, Oxford and elsewhere) where girls as young as 13 years old were abused and described by professionals as 'out of control', 'streetwise' and 'akin to prostitutes' (Delap, 2015; Morrison, 2016). Another example is the tragic suicide of a 14-year-old girl from British Columbia First Nations community, described by professionals as "street savvy", ignoring her distress, revealing a dysfunctional child protection system that is not reaching the children who need it most (Turpel-Lafond, 2014). This strongly resembles 'The Maiden Tribute of Modern Babylon', W.T. Stead's exposure of child prostitution in London, published in the Pall Mall Gazette in 1885. Drawing on Bhaskar's $(1989 ; 2014)$ critical realist ontology, we argue that to fully understand the lasting impact of the 'deserving/undeserving' paradigm it is imperative to place this in a stratified discursive and non-discursive context, taking account of causal mechanisms at three levels - personal; material and institutional.

In this article we explore the ongoing role and influence of the 'deserving/undeserving' paradigm, introduced by the New Poor Law of 1834, distinguishing between families/children who were and were not entitled to help and support. This research aims to investigate causal factors (individual, material, institutional) and social structures that impact on the continued legacy of the 'deserving/undeserving' paradigm, i.e. the notion that interventions and approaches towards safeguarding, mental health and wellbeing in childhood are variable and obtuse, favouring some and not others. This research draws on two data sets, namely historic children's case files $(\mathrm{N}=108)$ from 1881-1918 from the Children's Society's (a philanthropic institution formerly known as the Waifs and Strays Society) highlighting the perception of custodians, doctors and professionals, as well as children and parents and current data from interviews with young care leavers and safeguarding practitioners $(\mathrm{N}=42)$. 
Drawing on Bhaskar's (2014) critical realist ontology, we adopt a form of reasoning called retroduction, which involves moving from the level of observation and lived experiences to making (non-linear) inferences about underlying structures and mechanisms that may account for the phenomena involved. The key question here (and the focus of this article), is what mechanisms and causal factors (such as budget cuts, changing thresholds and related policies, as well as fragmentation in the care system) are at play and what is the legacy of the 'deserving/undeserving' paradigm. This will be explored in more detail below.

\section{Method: Critical Realism \& the 'Deserving/Undeserving' Paradigm}

Critical realism's central tenet is to promote awareness as a key strategy for tackling oppression, providing insight into the causal non-linear dynamics and generative mechanisms in the individual, the cultural sphere and the wider society. A central ontology of critical realism is that the world consists of social structures, is differentiated and stratified; to make sense of social life, we must understand the interplay between human agency (meaningmaking, motivations, intentionality) and social structures (enduring patterns, social rules, norms and laws) (Fitzpatrick, 2005; Houston, 2010). Here causal or generative powers are regarded as necessary tendencies of agents, social objects and structures, which may or may not be activated depending on conditions (Sayer, 2000). Taking historical and contemporary perceptions regarding safeguarding and child protection as a starting point, the approach adopted here works at what Bhaskar (1989) calls the 'real' level (exploring causal mechanisms that generate events, such as the availability of services), the empirical level (experienced events, e.g. in relation to trauma, abuse and stigma) and the 'actual' (events and processes in relation to child protection and safeguarding).

Popular discourse around 'deservedness', e.g. in relation to the vulnerability and/or malevolence of different types of children and their families often act as a locus for the 
manifestations of stigma, prejudices and deeper-seated anxiety, including perceptions of lifestyle choices, social-economic background and cultural characteristics (Morrison, 2016). Critical Realism influences the search for generative mechanisms, which might have combined to create a phenomenon over time, influencing particular outcomes and practices (Mutch, 2014). For example, historically bio-medical theories of inheritance and biological determinism in relation to 'mental deficiency', encouraged the belief that some individuals were biologically degenerate without hope of reform (Pilgrim, 2014). One example of a common mental classification used in relation to heritability in the early 1900s was 'feeblemindedness', which was often linked to 'moral incompetence' (Sohasky, 2015). Whilst 'feeblemindedness' is no longer used, there is evidence that 'moral competence' and 'moral incompetence' are terms that are still applied to child behaviour in certain situations. For example, a sexually abused child may bring to their foster placement challenging behaviours, some of which will be sexualised, and foster carers may inappropriately manage the situation by punishing the child for their 'immoral tendencies' (Fisher, 2000; Hardwick, 2005). In addition to this, there is evidence that social workers view their clients (usually mothers) as motivated to change if they agree with them and as resistant, and therefore 'risky' as parents if they do not (Holland, 2000). Links are also made to social and economic factors that contribute to the 'respectability' of families and children, such as in the case of the sexual exploitation scandals discussed earlier on.

For social care and child protection, this means that there needs to be a recognition and awareness of social structures and conditions which re-affirm or challenge its essential remit within to care, control and cure, including the day-to-day contradictions involving the 'personal' and 'political' (Fitzpatrick, 2005; Houston, 2010). Without this, there is a danger that judgements are made on the basis of who is 'deserving' and 'undeserving' of support. It 
should however, also be acknowledged that the complexity of definitions, conceptualisations and understandings of childhood, where some focus on the 'innocence of the child' and others view the child as an active agent in the perpetuation of pauperism through truancy and 'bad' behaviour, means that there is not a neat fit between childhood and the 'deserving/undeserving' paradigm (Morton, 2014).

The tenets of critical realism encourage a focus on the interaction between structure and agency in stratified entities, viewing context or situational influences as crucial to an understanding of processes and emergent outcomes (Kessler \& Bach, 2014; Saka-Helmhout, 2014). This is different to a focus on generalizable laws postulated by positivists, or the emphasis on lived experiences or beliefs of social actors inherent in interpretivism. Our goal is to identify instances of the phenomenon under investigation and subsequently determine which conditions precede its appearance. Drawing on data from two data sets, one with a focus on historic case files/reports from children taken into care between 1881-1918 and one based on interviews with young care leavers and practitioners (between 2015-2018), this research aims to explore the interaction of agency and structure in contexts which have been shaped by long-run factors (Mutch, 2014). In accordance with the UK Data Protection Act (1998) and the more current General Data Protection Regulation (GDPR), which came into force on May 25, 2018, it was decided that it would be more appropriate to draw on interviews for the contemporary data set; access to case reports for the contemporary data set would have been problematic. The case files linked to data set one were in compliance with the 100 year data protection rule.

By comparing and contrasting historical and contemporary data, it is possible to gain insight into historically conditioned conceptions, their (non-linear) generative mechanisms, in 
relation to long-run (e.g. institutional and political) and shorter run factors (such as demographics and geographical location). For parity and in line with Stein's (2006) definition of 'victims', the focus of this study, only participants with complex (mental health) needs and damaging (pre and/or post) care experiences were included in this research.

\section{Participants and Procedure}

Data set one consists of data from the Children's Society's (formerly known as the Waifs and Strays Society) children's case files from 1881-1918 highlighting the perception of custodians, doctors and professionals, as well as children and parents. About 22,500 children in England and Wales were looked after by the Waifs and Strays' Society between its foundation in 1881 and the end of the First World War in 1918; 108 case files were selected through keywords with a specific focus on complex (mental health) needs and pre/post care experiences.

Sampling of data for data set one was undertaken through a search of the online database (https://www.hiddenlives.org.uk/) and visits to the Children's Society archives in London. The online search, visits to the archives and subsequent in-depth analysis resulted in a selection of 108 case files (69 related to females and 39 related to males) that involved children/young people with particularly damaging care experiences, specifically in relation to mental health (of the child and/or the parent), abuse/neglect and damaging pre/post care experiences. The average age of the participants in data set one was 10 years old at the time of the application to the Waifs and Strays Society, with the youngest 2 years old and the oldest 16 years old. Case files contained correspondence from custodians, educators, medical officers, church reverends, practitioners linked to asylums and industrial schools, and parents, whilst the children were in care and on some occasions post-care (e.g. from the Aftercare association, the Girls Welfare department, Children's Homes and employers). In addition to this, a number of the files 
contained correspondence from the children and young people whilst they were in care and post-care ( $\mathrm{N}=18$, aged between $10-50$ years old).

'Mental issues' were discussed in relation to 69 of the children (keywords: mental illness; depressed; lunatic; insane; anxiety; mental deficiency; mental condition; mental capacity; mental trouble; unsound mind; acute mania; hysterical; melancholia; nervous breakdown; neurotic condition; imbecile; sensitivities; delicate nature; weak intellect; feebleminded; weakminded; congenitally deficient; brain trouble). In a total of 25 cases, reference was made to admittance to a mental asylum - 13 children (ten females and three males) spent time in an asylum before they turned 18 years old; 7 (one male and six females) spent time in an asylum from age 18 onwards and in relation to 5 children (all female) there was both talk of entering an asylum prior to turning 18 and after they were 18 years old. In the majority of the cases the families were described as dysfunctional (e.g. 'wretched', 'immoral'); in 22 of the cases one of the parents (usually the mother) was in an asylum. In 18 of the cases files, reference was made to child abuse/neglect. Suicide was referred to in 18 of the cases (of which 6 were successful).

Data set two comprises of semi-structured interviews $(\mathrm{N}=46)$ with young care leavers $(\mathrm{N}=24$; mean age 18.5 years old) and safeguarding practitioners $(\mathrm{N}=22)$, undertaken in the South of England between 2015-2018, with a focus on pre/post care experiences and related support (it should be noted that every year around 10,000 16 to 18 year olds leave foster or residential care in England, see DfE, 2015). All care leavers in this study had been in the care system from an early age and had received support through CAMHS (Child and Adolescent Mental Health services) and other agencies (social work, care workers and additional counselling services) in the past; half of the participants had transferred to adult mental health services, whilst the others did not meet the threshold and/or were supported through other means. All 
participants were living in supported accommodation at the time of the interview and all had an unstable care trajectory (in line with Stein's (2006) definition of 'victims').

Of the twenty-four care leavers who took part in the interviews, eleven were males, and thirteen were female; seven of the participants were from a BME (black and minority ethnic) background ( 2 males -5 females). Note that none of the participants in data set 1 were from a BME background. On average, the participants had spent ten years in care. The 22 (two males and twenty females; one was from a BME background) safeguarding professionals comprised of eight care-workers linked to family support charities and children's charities catering for children in care, care-leavers and vulnerable families, three family services managers; three service leads for young people's support and housing, four safeguarding officers linked to three secondary schools, two community care workers and two managers of a family centre. Data protection rules were followed and ethical consent was obtained for the interviews and the research was reviewed and approved by the University Ethics committee.

\section{The three phases of analysis}

The research consists of three phases (in line with Authors, 2007; Authors, 2014). Phase one adopts a form of analysis with a focus on 'discovery' or retroduction in terms of the notion that this research seeks to develop as broad as possible an understanding of what factors might be relevant and then to test this iteratively against new information. To start this phase, a thorough and focused review of relevant (historic and contemporary) literature, policy documents and secondary data was conducted from as wide a perspective as possible allowing us to identify the most common recurring elements of embodiment, institutions and materiality that impact on the participants in the data sets (e.g. psychological and political structures, as well as contextual factors). Contrary to a literature review, which provides the theoretical basis for a piece of research and determines the nature of the research, this phase 
turns to literature and research to identify some of the entities that may combine to form causal factors.

In phase two, thematic content analysis was applied to the data (both the historic and contemporary data), in order to identify themes within each data set and, compare patterns and contrasts within and across the sets. Thematic content analysis depicts the thematic content of interview transcripts and texts by identifying common themes in the texts provided for analysis (Anderson, 2014). A common list of themes were grouped and distilled from the data in order to provide insight into the communality of voices across the participants. Thematic content analysis was perceived as useful here, as it allows for both a quantification of data (through content analysis focus on measuring the frequency of different categories) and a qualifying narrative focus (through thematic analysis) (Vaismoradi et al., 2013). Phase three introduces the critical realist aspect, by examining the data in terms of how participants' personal, material and institutional contexts may provide the conditions for sense-making.

\section{Data Analysis}

This section focuses on differences and similarities between the two data sets. Obvious differences were found in the language applied to 'mental health issues' in children; terms, such a 'feeble-minded', 'insane' and 'imbecile' are no longer in use. Interestingly though, in both data sets there were examples of failings in relation to supporting the most vulnerable children; the children referred to by Stein (2006) as 'victims', with complex (mental health) needs and damaging (pre and post) care experiences. For example, in both data sets there was evidence that responsibility for this group of children is passed on to others and/or discussed as out of the remit of the agency/Home involved. Some interesting similarities between the two data sets were also found in the correspondence of (data set 1) and interviews with (data set 2) children and young people, most notably around how the young people positioned themselves 
in relation to being 'grateful for the support' and apologetic for their 'bad behaviour'. What the children and young people in both data sets have in common is their personal history of being in the care system with complex (mental health) needs, as well as their material context, placing them on the margins of society with no privileges at all; something that is reflected in both their narratives and the narratives of the professionals who work with them.

Themes were identified through data emersion; both data sets were given equal attention, so that full consideration could be given to repeated patterns within and across the data. Key themes are identified in Table 1 and 2. Table 1 summarises the themes linked to the correspondence from (data set 1) and interviews with (data set 2) safeguarding professionals; table 2 summarises the themes from the correspondence and interviews with young people in the respective data sets.

Table 1: Data from Safeguarding officers and practitioners

\begin{tabular}{|l|l|l|}
\hline Themes & $\begin{array}{l}\text { Data set 1 - Waifs \& Strays } \\
\text { Society, 1881-1918; } \\
\text { Correspondence about the } \\
\text { child, N=108. }\end{array}$ & $\begin{array}{l}\text { Data set 2 - interviews with } \\
\text { safeguarding practitioners, } \\
\mathrm{N}=22 .\end{array}$ \\
\hline 'Beyond help' & $46 \%(\mathrm{~N}=50)$ & $50 \%(\mathrm{~N}=10)$ \\
\hline $\begin{array}{l}\text { Child/family needs as } \\
\text { central }\end{array}$ & $19 \%(\mathrm{~N}=20)$ & $50 \%(\mathrm{~N}=11)$ \\
\hline $\begin{array}{l}\text { 'Problematic children' } \\
\text { (mental health issues and } \\
\text { behavioural issues) }\end{array}$ & $76 \%(\mathrm{~N}=82)$ & $59 \%(\mathrm{~N}=13)$ \\
\hline
\end{tabular}

Table 2: Data from Young People

\begin{tabular}{|l|l|l|}
\hline & $\begin{array}{l}\text { Data set 1 - Waifs \& Strays } \\
\text { Society, 1881-1918; } \\
\text { Correspondence from the } \\
\text { child, N=18. }\end{array}$ & $\begin{array}{l}\text { Data set 2 - interviews with } \\
\text { care leavers, N=24. }\end{array}$ \\
\hline 'Grateful' & $44 \%(\mathrm{~N}=8)$ & $63 \%(\mathrm{~N}=15)$ \\
\hline
\end{tabular}


Table 3 (see appendix) summarises the outcome of phase 1 of the study and provides examples of psychological and political structures and institutions, as well as contextual factors in relation to the two data sets; note that this table is by no means exhaustive. In line with the critical realist approach discussed earlier on, these factors are treated as non-linear dynamics and generative mechanisms that may or may not be activated depending on conditions. The themes are illustrated by the extracts from each data set presented below, which will be analysed in light of phase 1-3. The first theme 'beyond help' highlights narratives with a focus on 'rejecting' children, e.g. turning them away and positioning their needs as too complex to cater for.

\section{Beyond Help}

\section{Data set 1:}

The example discussed below is linked to case 6001; a boy born in 1894, who was taken into care in 1906 when he was 12 years old. His parents were both dead and he is described as an illegitimate child., In the correspondence (dated 1906-1913) he is described as 'frequently very peculiar in his manner'; a letter from the Medical Officer (1907) describes his intellectual capacity a subnormal; He is referred to as, 'hard to place' and spends time in various Homes and institutions. Included in the correspondence is also a letter from the boy indicating that he is, 'grateful for the support'. He ends up in the workhouse, from which he runs away in 1910. In 1913, when the boy is 19 years old, there is a letter, from the Boys Farm Home, an after-care training centre:

This lad (nearly 20) is so seriously deficient mentally, and becoming worse, that I do not care longer to have him among the other boys. In consequence of the above fellow's mental condition he is unfit to remain in the Home, and under the circumstances am afraid that the 
Union is the only alternative. Will you be so good, therefore, as to kindly see what you can do with a view to securing his admission to the local Workhouse in order that the Poor Law authorities, who have the means and power to provide the special training and care he evidently needs, can deal with the case.

Throughout the case file, there is a suggestion that the various service providers (Children's Home, as well as the after-care training centre) are unable to cater for this boy. Here an association is made between him being, 'so seriously deficient mentally' and a need for his admission to the local workhouse. Thus, in light of his complex needs, it is decided that the only option left to him is that of the workhouse. The fact that the Poor Law authorities are constructed in terms of providing the, 'special training and care he evidently needs', should be seen in light of their harsh philosophy distinguishing between the deserving and undeserving poor (Author, 2017); it could be argued that in this case the latter applies to boy in the case file above.

Data set 2:

In data set 2 , reference was also made to an inability to deal with problems that the young person is presenting. The extract below comes from an interview with a safeguarding practitioner at one of the leading family support charities in England. The interview is around the services provided by the charity and in the discussion below the conversation turns to working with complex families:

We are finding now, that there are a lot more complex families coming to us. Who have already hit crisis, and that's not what XXX was originally for, but it feels like now that there are gaps in the other services so we are getting more complex families who have already gone further down the kind of child protection journey.

I know there was one family where there was a young Mum who had quite a long track record of domestic abuse and she was a young Mum of, eighteen I believe, anyway, had two young children, was in a relationship again with an older man. There was history of her being in relationships with people whether, I think two men who had been convicted of child abuse. And previously we felt like services would have been there supporting her, getting her 
on to things like the empowerment program and, it's sort of seeing her as a real risk and seeing her children as at risk, and she was a care leaver as well so she had very little family support. But there didn't seem to be any care leavers' services or anything supporting her. And, when, when one of our volunteers went in to work with her, it was a lot more than they'd had training for because there, there were a lot of issues that actually we didn't know about, so when the health visitor had referred her on they hadn't been open about all the history of domestic violence and we do work with domestic violence but as long as we know about it. So when we then turn up and find out about the domestic and the history of sexual abuse and there's a man in the house that we don't know about, then that's a situation we 're not happy to work with.

As with data set 1 , in the extract above a link is made between 'complex families' and an inability to cater for them ('that's a situation we're not happy to work with'). In this case, the charity is passing the buck by positioning the family as unsuitable for (their) services.

Research shows that people are most prone to passing the buck when they risk being responsible and possibly blamed for a bad outcome (Steffel et al., 2016). This is also evident from the reference to domestic abuse, the talk about the history of the young mother being in relationships with unsuitable males and the fact that she is seen as a 'real risk' (in relation to herself and her children). The last decade saw an increase in child protection cases in the UK and the implementation of safeguarding measures (e.g. by taking children into care) as a result of domestic violence (Hilder, \& Bettinson, 2016). Domestic violence is now recognised as a public health issue and a significant child protection concern (Rivett \& Kelly, 2016) with associated policies and legislations such as the Domestic Violence, Crime and Victims Act (2012). Yet, cuts to services, lack of joined up working between agencies and being classified as a 'real risk' and a 'complex family', such as the family in the extract above, means that they are missing out on the help they so desperately need.

\section{$\underline{\text { Child/family needs as central }}$}


As well as examples of failure to support 'victims', there are also examples (in both data sets) of a desire to provide support and strengthen collaborative networks, by taking the voice of the child/family as the starting point (addressed in 19\% for data set 1 and $45 \%$ for data set 2).

\section{Data set 1}

The extract below is linked to Case 18451, a girl born in 1904, who is taken into care in 1914. Correspondence dates from 1914 to 1924 and includes a letter from the girl to the Waifs and Strays society (in 1921) in which she says that, 'I feel very grateful for all your kindness to me during the past years'. Throughout the correspondence there is reference to her 'mental condition', 'peculiarity of temperament', 'mental derangement' and 'insanity'. The Medical Officer links this to her menstrual periods, whilst correspondence in 1914 actually indicates that, 'the girl has been criminally assaulted and that the appearances support the child's own story that the assaults have been of frequent occurrence'. The reaction to this is mixed (as she appears to be moved from one place to another), but there is also evidence that her needs are perceived as central by some:

I always feel that it is important for a young person to be kept in personal touch by the authorities and that the girl would hardly have proved so unsatisfactory had she been kept in personal touch with the Authorities of the School to which she was committed.

The word 'personal' is underlined by the matron who wrote the message above. The focus on the personal stands in stark contrast to the reference to 'unsatisfactory', and the fact that things clearly have not gone well for this girl. However, it also puts the people who have let her down so much, and treated her as undeserving, in their place. In the final analysis, and despite the caring tone of the extract above, there is a clear sense that the Charity Organisation Society and Poor Law Authorities have failed in developing a system of personal social work for this person (Thane, 2012). 


\section{Data set 2}

The extract below comes from a manager of a family centre who is in charge of providing early support services for vulnerable families and young people. Below, she discusses how she puts the perspective of the families at the core and how this has impacted on her practice:

We have taken feedback from families recently, and some research that has been done broadly around the multiagency teams, is that families would prefer to have a team around the worker and just have one worker to themselves. So we are shifting to a model of team around the worker now. So that won't negate the idea that families will work with more than one professional because clearly in some cases, that is going to be required, if you've got a specialist, if you had someone who had perhaps a significant mental health issue they will still need mental health support.

In the extract above the model of the 'team around the worker' is constructed in terms of something that was instigated by research with families, thereby positioning their needs centre stage. However, this should also be seen in light of ongoing cuts to support and early intervention services, with almost a quarter of services cut in the South (Action for Children et al., 2017), meaning that choices will need to be made about who is receiving the help and who is not. As can be seen from the extract above, a suggestion is already made that 'significant mental health issues' need to be catered for in a different way.

\section{A problematic child - Mental health issues and Behavioural issues}

In both data sets 'mental health issues' and 'bad behaviour' in children were discussed as problems that affected the way in which professionals were able to care for the child, leading to constructions of children with mental health issues and behavioural problems as 'problematic children'. Often the blame and responsibility was put on the child and their family here, positioning them as undeserving of help.

Data set 1: 
The case discussed below (10746) is about a girl who was taken into care in 1904, aged 4 years old. Correspondence related to the girl is mostly from the Waifs and Strays Society and different children's Homes where she resides. There is reference to her 'immoral surroundings' and in 1917, when she is 17 years old, there is reference to her being 'mentally deficient' and that she will be, 'handed over to the local infirmary so that she may be under observation'. In the correspondence there is also reference to her behaviour: 'a furious outbreak of temper' and that she is, 'inclined to be sulky and morose, which somewhat handicaps her and makes her erratic and difficult'. All of this culminates in the following letter from the Society, in 1918:

How exceedingly I regret that the girl should have proved more or less such a failure, after all the care that she has received during the many years she has been in the Society's care. I can assure you that everything possible has been done for the girl and neither time, trouble or expense has been spared on her behalf, but it is very evident that she has strong hereditary tendencies of an unsatisfactory type.

The extract above portrays the Society as caring, sparing no time, trouble or expense in caring for this young girl, who turns out unsatisfactory, and 'more or a less a failure', not only in her behaviour but also because she is 'mentally deficient'. In line with popular psychology/psychiatry of the time (see Rey et al., 2015) the focus here is on her hereditary tendencies. Both her 'immoral surroundings' and 'furious outbreak of temper', as well as her 'mental deficiency' and 'hereditary tendencies' render her as undeserving.

\section{Data set 2:}

A similar trend can be seen in contemporary discussions around child behaviour. The extract below is about a teenage boy whose behaviour has deteriorated to the point that staff at a behavioural, emotional and social difficulties school are struggling to cope. The data comes from an interview with a safeguarding officer in the school (who is also the Deputy Headteacher of the school): 
Because we've had quite a few cases, like I was saying, where staff are assaulted, or there's huge amounts of criminal damage. And where there's this policy about not criminalising children, that actually is quite hard for us to get our heads around, because, well we are a social, emotional and mental health school, so we have pretty much the naughtiest children in the city and whilst I understand that a good kid who does one bad thing is not a criminal, we have one young person who has had ninety one criminal offences. And that's a way beyond a good kid doing one thing bad, sometimes these are criminal children doing criminal activities repeatedly, repeatedly, repeatedly, and at that, at some point, restorative is not good enough, it's not working.

In the extract above, a direct link is made between being a 'social, emotional and mental health school' and working with, 'the naughtiest children in the city'. As with the extract from data set 1 , the child is held accountable and constructed as beyond help (i.e. 'undeserving'). The extract refers to 'restorative' practice, which is widely used in school settings and practices in England as a way to work through, resolve and transform conflicts (Zehr, 2015). Yet, in the context of this young person's behaviour, it is felt that this approach is no longer viable.

Sexualised behaviour and related consequences for support (or lack of) was also discussed in both data sets below:

\section{Data set 1}

This is a case study (7978) regarding a girl who was found wandering the street in in 1901 when she was 11 years old. She was taken into police custody and remanded on the charge of having no proper guardianship. Included in the correspondence is a letter saying that, 'The girl's habits are bad, and she was the subject of an indecent assault, for which a man was tried and sentenced to penal servitude'. She is taken on by a Home in 1903, and there is talk of her 'trying to strangle herself' and 'having terrible fits'; A medical report at the same time refers to the girl being a 'hysterical type'. There is also a letter from a vicarage in 1903 referring to her 'impure language': 
It is not childish naughtiness which one could understand and reason with, but a diseased mind, mostly owing to her miserable and ruined life in the past. Children pick up good and evil so quickly, it does seem wrong to let so much POISON get among them'

The girl in the extract above is referred to the Waifs and Strays Society on account of having no proper guardianship. From the correspondence it is evident that she was the subject of an indecent assault. Moreover, it is acknowledged that her, 'miserable and ruined life in the past' still influences her today, thereby recognising that there are multiple factors involved in the development of mental health issues in children (Rey et al., 2015). She is also referred to as being a 'hysterical type', one of the first mental disorders specifically attributable to women and, until Freud, considered an exclusively female disease (Tasca et al., 2012). Yet, despite this and the fact that safeguarding measures (the NSPCC, and the Prevention of Cruelty to and Protection of Children Act) were in place at the time, this girl appears to be solely measured against her behaviour and her 'diseased mind' and 'impure language', resulting in a request for her removal from the Home. Authorities were concerned that girls who had been exposed to sexual behaviour would have a corrupting influence on other residents and would remove them (Digby \& Wright, 1996, Jackson, 2000).

\section{Data set 2}

A similar trend is evident in data set 2 . The extract below comes from a service manager and safeguarding officer at a centre providing housing and support for homeless young people (aged between 16-25 years old). The extract identifies the sexual behaviour of one of their clients as a risk factor, leading to removal from the centre:

But then it's just because, I'm not saying that's, you know, unmanageable because what we do is we unpick it and find who we need to find and eventually we end up either being able to manage it or not and on several occasions though its happened where we haven't been able to manage it. There was a girl, I can't give names obviously, but there was a girl, either last year or the year before and she came to us and her mental health, just to look at her, 
certainly the way she behaved she wasn't well, always in very high risk situations, really high risk, we've had members of staff you know, grabbing, trying to grab her hand while she's got bottles, trying to cut her neck, really quite high level and we had such a battle to get mental health services to realise that she shouldn't be here, and actually being here she wasn't only putting herself at risk, she was putting other people at risk because she had quite tricky sexual behaviour.

As with the previous extract, in the interview above the behaviour of the young person ('the way she behaved she wasn't well'), as well as her mental health, 'high risk situations' and 'tricky sexual behaviour' are all used to classify her as unsuitable for the services provided by the centre. Thus, there is a suggestion that in a climate of ongoing cuts to services and facilities and changing thresholds for support (Action for Children, NCB, and The Children's Society, 2017) the Local Authority is failing in its duty of care to provide services for the most vulnerable group of young people, leading to them becoming victims of the system.

In both data sets there was evidence that the young people were grateful for the help and support they received (44\% for data set 1 and $33 \%$ for data set 2), as well as making themselves accountable for their (at times) 'bad behaviour' (68\% for data set 1 and $41 \%$ for data set 2). See below for examples of the themes, 'grateful for help' and 'I used to be bad':

\section{Grateful for help}

Data set 1

The extract below comes from case file 485, a boy born in 1880 who was taken on by the Waifs and Strays Society in 1885 on account of being an illegitimate child. He appears to be living in different Homes, and there is a letter from Mr Rudolph (the founder of the Waifs and Strays Society) in 1892 enquiring whether the boy is in, 'good health and not suffering from any complaint'. Included in the correspondence is a letter from the boy to the Waifs and Strays Society when he is 19 in 1899 : 
Your humble servant Harry E takes the opportunity and think it his duty to write and let you know how I am getting on, and also to thank you for the many kindness you have done for me, I am getting on very well in my new place and I like it very much.

The boy in the case file above clearly positions himself in a subservient role ("your humble servant') in relation to the concept of being worthy and deserving of the help and support that he received through the Waifs and Strays Society. Moreover, he also indicates that he is now able to look after himself and is no longer a drain on society, thus not falling foul of the harsh philosophy of the New Poor Law (Author, 2017) . A similar approach can be seen from the interviews with the young care leavers.

Data set 2:

The extract below comes from an interview with a young male (aged 21 years old). He has had an unstable care trajectory; he was taken into care when he was 7 years old due to abuse and neglect and, has spent time in multiple children's homes and with various foster parents. Currently he lives in supported accommodation. In the extract below he refers to his current support worker, who is linked to a local Children's Charity:

I'm being honest when I say that if it wasn't for my worker I genuinely think I'd be dead by now, probably killed myself or at least on the streets and probably a crackhead. There are times I have been really low and depressed, but I have my worker who I can talk to and they listen and support me to keep going. They've never let me down and have gone of their way for me and given me the time when I've needed it.

The account above should be viewed in light of this participant's unstable pre and post-care experiences and social position, placing him on the margins of society. Despite the recent 'Staying put arrangement', with a focus on supporting young people to continue to live with their former foster carers once they turn 18 (DfE, 2015), there is evidence that he has not been able to benefit from this. As such, he is grateful for the support of his care worker, who 
is positioned as the hero who saved his life: 'if it wasn't for my worker I genuinely think I'd be dead by now'.

As well as expressing appreciation for the help and support they received, the young people in both data sets also positioned themselves as 'bad' and 'undeserving'. See below for examples:

\section{$\underline{\text { I used to be 'bad' }}$}

Data set 1:

The extract below links to Case file 7884, a girl born in 1890 who was found wandering the street in 1904 when she was 14 and was subsequently taken into care. She is taken on by one of the Homes linked to the Waifs and Strays Society and is described (in 1904) as having a, 'very wild look in her eyes' and that, 'she threatened to take her own life'. There is also reference to her 'family history', and her talk about suicide, which is treated as something that is, 'impurity of the very grossest kind'. There is also correspondence around her 'mental health condition' and the need for her to be charged under section 32 of the Industrial Schools Act and committed to a Reformatory School due to her, 'wilfully refusing to conform to the rules of the school'. Below is a letter from the girl written in 1904:

I have been a naughty girl again for the last three days, but the mistress has given me one more chance. I am going to church, going for walks and am working in the mistresses kitchen.

Despite the fact that there is reference to the girl's family history in the correspondence, and the acknowledgement, to an extent, that she has had a very traumatic past, her 'bad' behaviour takes centre stage. This approach is also adopted by the girl in question, when she acknowledges that she is a 'naughty girl'. Yet, this negates the fact that due to their pre-care experiences and related trauma, looked after children may have challenging emotional and 
behavioural difficulties (Fisher et al., 2000). Instead, the onus and responsibility are put on the young person, who is made accountable, and due to her 'impurity' is perceived as less worthy of help and support. There were similar examples in data set 2, and research shows that due to ever changing thresholds for receiving care, fewer children are able to access the services that they need, especially when moving from child to adult services (Beito, 2011; Fong et al, 2018).

\section{Data set 2:}

The interview below is with a female, aged 18 who has been in and out of care from an early age and has an unstable care trajectory. She has a two year old son and lives in supported accommodation. Below she holds herself accountable by referring to her aggressive behaviour:

I think she [care worker] taught me how to speak to people and not be like, I used to be quite aggressive and quite horrible and stuff like that and needed to learn to speak properly and not get wound up and say things in the right way.

As with the example from data set 1 , this young person also makes herself accountable by referring to being, 'quite aggressive and horrible'. By referring to saying, 'things in the right way' she takes ownership of the fact for someone in her position help and support is something that she has to earn, by learning to speak and behave properly, thus placing herself at the bottom of the 'deserving spectrum'.

\section{Discussion}

Child safeguarding and support practices have been in constant flux and need to be seen in light of the complexities and confusions of history and the legacy inherited from the nineteenth century child rescue movement (Cradock, 2014; Hacking, 1991). The current research shows that the focus on individual accountability and responsibility in our current society strongly 
resembles the 'deserving/undeserving' criteria promoted by the New Poor Law 1834 and related harsh philosophy of self-care and self-responsibility (Author, 2017).

A combination of factors influenced social work practice in England in the twentieth century, including the contributions of the COS (Charity Organization Society), voluntary sector and public sector employers (Burnham, 2011; Author, 2017). The nineteenth century rescue movement coincided with a shift in social policy from laissez-faire to social control over childhood, which underpinned childcare legislation. (Donzelot, 1997; Hendrick, 1997). Disapproval of lifestyles could result in the withdrawal of COS help, which could force the family into desperate circumstances and dependency on the state. The casework approach of the time was based on investigative methods to ascertain the cause of poverty, not the effect; and considered immediate material relief would not solve the problem long term (Author, 2017). Children rescued for child protection reasons such as neglect, or abuse and committed to care, could be caught up in the juvenile justice system and therefore criminalized (Cox, 2013). Contemporary attitudes towards children and families resonate with those in the late nineteenth century, including the casework methods practiced by the COS. As an example, austerity measures initiated by the Conservative and Liberal Democrat Coalition government in 2010 substantially reduced children's services through the closure of children's centres and lack of youth services, and the Welfare Reform and Work Act of 2016 can be seen to be in direct comparison to the curtailing of public spending in 1870 (Action for Children et al., 2017; Loopstra, 2015). Allocation of children to the juvenile detention system and the child protection system continues to be classed, raced and reliant on social position (see Cox, 2013; Einboden et al., 2011). Examples of this can be seen in the Serious Case Reviews (SCR) concerning the Child Sexual Exploitation scandals in England, and further afield in the suicide of the First Nations Girl in Canada (Morison, 2016; Turpel-Lafond, 2014). In both cases, the victims were described as streetwise and out of control and their distress was ignored.

This study is unique and innovative, as it fills a gap in the current literature on child safeguarding practices in that it provides insight into historical and contemporary practices 
simultaneously revealing the legacy of the 'deserving/undeserving' paradigm in practices affecting the most vulnerable children. Child protection is fundamentally political, because of the broad range of definitions and specialist epistemologies associated with this (Cradock, 2014). This research shows how this complexity is negotiated by representing the most vulnerable and disadvantaged children ('victims') with complex (mental) health needs and damaging care experiences, as the 'other', as 'unsuitable for services' and 'unmanageable' due to their multitude of problems, for which they themselves are held accountable (Joffe, 2003). Self-Other distinctions are central to social and temporal spaces and identities and research shows that specific social groups are often presented as the 'Other' (e.g. gypsies, people with mental health issues) (Knaak et al., 2017; Powell, 2008). The concept 'Othering' refers to the reductive action of labelling and defining a person or a group of people as belonging to the socially subordinate category of the 'Other' (Roberts \& Schiavenato, 2016). 'Othering' is achieved through a number of distinct representational pathways, namely through representational absence, through representations of difference, and through representations of threat (Chauhan \& Foster, 2014). The current research provides some important indicators that both at present and in the past 'victims' are viewed through the lens of 'difference' (stigma and labels) and 'threat' (e.g. financial, moral), instigating judgements in relation to 'deservedness'.

What the participants in both data sets have in common is their personal history of being in the care system, as well as their material context, placing them on the margins of society with no privileges at all. The participants' social position could, therefore, be understood as providing the 'scaffolding' for their positive construction of the input of the care worker/children's Home, as it reflects their (real and perceived) lack of entitlement. Not only that, the focus on their 'bad behaviour' hints at the fact that in the greater scheme of things they are not all that 'deserving' of the help and support that they so desperately need. Yet, 
this negates the fact that due to their pre-care experiences and related trauma, looked after children have challenging emotional and behavioural difficulties, as a result of which a significant number of placements break down and children experience numerous placements (Fisher et al, 2000; Hardwick, 2005).

Thus, comparing data from the case files against current data from interviews with young care leavers and safeguarding professionals, highlighted some interesting similarities, specifically in relation to perceptions of the child's behaviour, abilities and intentions. Framing this within a critical realist ontology and epistemology means taking account of the stratified non-linear dynamic nature of processes at different levels, such as the real level (namely causal mechanisms that generate events). In both data sets the inability (or unwillingness) to support those children is justified by referring to the multitude of their problems, mental health, behavioural and complex needs, meaning that in the greater scheme of things they either do not meet the threshold and/or are constructed as beyond help; within this the child is held accountable and placed in the 'undeserving' category.

\section{Limitations and opportunities}

Comparing data across two very different timescales is challenging and it should be acknowledged that in the twenty-first century the experience of childhood is very different compared to the late 1800 s. This research only showed one part of this, namely the experiences of 'victims', disadvantaged children, with damaging care experiences and complex (mental health) needs (Stein, 2006). This article shows how the growth of child philanthropy in the late 1800s coincides with a shift in cost-cutting and how this could be seen as foundational to the social work that grew from it and, perhaps, even as an early example of the state outsourcing care of children to private interests. However, within this it is also legitimate to acknowledge the inter-war years, the 1950s, 1960s and related developments in child safeguarding. 
Nevertheless, by comparing historic and contemporary data simultaneously, this research has provided insight into the interaction of agency, structure and social contexts that have been shaped by long-run factors in a constructive way.

Taking a critical realist lens then allowed the analysis to contextualise this sense making within ('real') statistical patterns that show causal effects between, for example, the power of institutions in different eras (and related thresholds and perceptions), as well as the material contexts and social position of the participants. As such, we can see how phase one identifies potential causal events (to use the language of critical realism) that may produce experienced events (such as being marginalised), which in turn is accounted for from both an experiential standpoint (i.e. how it made the participant vulnerable) and accountability standpoint (leading to judgements from practitioners about 'worthiness' and 'deservedness'), especially when resources are scarce. This has implications for practice in that this study challenges the prevailing viewpoint and focus on early intervention/prevention, locating problems in families and parenting, and instead turns towards historic and contemporary uneven safeguarding practices and related subjective distinctions between those who are 'deserving' and 'undeserving' (e.g. in relation to perceived behaviour and lifestyle choices). Within this, this study highlights a need for more awareness and equality and diversity training opportunities for practitioners and professionals, and for safeguarding officers to be more reflective and reflexive in their practices with vulnerable children and families.

\section{Acknowledgements}

With specific thanks to Dr Simon Edwards and the Roberts Centre, Portsmouth for support with data collection and the Children's Society in London for providing access to their archives. We would also like to thank the Wellcome Trust for providing funding for this study (Grant reference number: 205858/Z/16/Z, 'Mental Health in Childhood').

\section{References}


Action for Children, NCB, The Children's Society (2017). Turning the tide. Reversing the move to late intervention spending in children and young people's services. Available at: https://www.childrenssociety.org.uk/sites/default/files/turning-the-tide.pdf. Accessed: Accessed: $24^{\text {th }}$ August 2018

Anderson, R. (2004). Intuitive inquiry: An epistemology of the heart for scientific inquiry, The Humanistic Psychologist, 32 (4), 307-341.

Bouma, H., Lopez Lopez M., Knorth, E.J., Grietens, H. (2018). Meaningful participation for children in the Dutch child protection system: A critical analysis of relevant provisions in policy documents, Child Abuse \& Neglect, 79, 279-292.

Burnham, D. (2011). Selective memory: a note on social work historiography, British Journal of Social Work, 41, 5-21.

Chauhan, A. and Foster, J. (2014). Representations of poverty in British newspapers: a case of 'othering' the threat? Journal of Community and Applied Social Psychology, 24(5), 390405.

Cox, P. (2013). Bad Girls in Britain, Gender, Justice and Welfare, 1900-1950. Basingstoke: Palgrave.

Cradock, G. (2014). Who Owns Child Abuse? Social Sciences, 3, 854-870.

Crompton, F. (1997). Workhouse Children, Stroud: Sutton.

Delap, L. (2015). Child welfare, child protection and sexual abuse, 1918-1990, History \& Policy. [Online]. Available at: http://www.historyandpolicy.org/policy-papers/papers/childwelfare-child-protection-and-sexual-abuse-1918-1990.

DfE (Department for Education) (2015). Children looked after in England (including adoption and care leavers) year ending 31 March 2015, SFR 34/2015, 1 October, [Online]. https://www.gov.uk/government/uploads/system/uploads/attachment_data/file/464756/SFR34 _2015_Text.pdf.

Digby, A. and Wright, D. (1996). From Idiocy to Mental Deficiency, Historical perspective on people with learning disabilities, London: Routledge.

Donzelot, J. (1997). The Policing of Families.Baltimore: John Hopkins University Press.

Einboden, R., Rudge, T., \& Varcoe, C. (2011). Battling the passions: The birth of a conceptual understanding of suspicion for child abuse and neglect. Aporia: The Nursing Journal, 3(2), 5-14.

Fisher, T., Gibbs, I., Sinclair, I. and Wilson, K. (2000). Sharing the care: the qualities sought of social workers by foster carers, Child \& Family Social Work, 5(3), 225-33. 
Fitzpatrick, S. (2005). Explaining homelessness: a Critical Realist Perspective, Housing, Theory and Society, 22(1), 1-17.

Fong, H-F., Alegria, M., Bair-Merritt, M.H. and Beardslee, W. (2018). Factors associated with mental health services referrals for children investigated by child welfare. Child Abuse \& Neglect, 79, 401-412.

Gingell, K. (2001). The forgotten children: children admitted to a county asylum between 1854 and 1900, Psychiatric Bulletin, 25, 432-434.

Hacking, I. (1991). The Making and Moulding of Child Abuse, Critical Inquiry, 17 (2), 253288.

Hardwick, L. (2005). Fostering children with sexualised behaviour, Adoption \& Fostering, 29(2), 33-43.

Harvey, D. (2007). A Brief History of Neoliberalism, Oxford: OUP.

Hendrick, H. (1997). Children, childhood and English Society 1880-1990 Cambridge: Cambridge University Press.

Higginbotham, P. (2017). Children's Homes. A History of Institutional Care for Britain's Young, Barnsley: Pen \& Sword History.

Holland, S. (2001). The assessment relationship: interactions between social workers and parents in child protection assessments, British Journal of Social Work, 30(2), 149-163.

Hood, R. (2016). How professionals talk about complex cases: a critical discourse analysis. Child \& Family Social Work, 21(2), 125-135.

Houston, S. (2010). Prising Open the Black Box: Critical Realism, Action Research and Social Work. Qualitative Social Work, 9(1), 73-91.

Hurren, E. (2015). Protesting about Pauperism, Poverty, Politics and Poor Relief in LateVictorian England 1970-1900, Woodbridge: Royal Historical Society.

Jackson, L. (2000). Child Sexual Abuse in Victorian England, London: Routledge,

Joffe, H. (2003). Risk: From perception to social representation, British Journal of Social Psychology, 43, 55-73.

Judkins, B. (1948). Adoptive Parents in a Child Guidance Clinic, American Journal of Orthopsychiatry, Mental Health \& Social Justice, 18(2), 257-264.

Kessler, I. and Bach, S. (2014). Comparing Cases. In: Edwards, P.K., O'Mahoney, J. and Vincent, S. (Eds), Studying Organizations Using Critical Realism, (168-184), Oxford: Oxford University Press.

Knaak, S., Mantler, E. and Szeto, A. (2017). Mental Illness-related stigma in healthcare, Healthcare Management Forum 32(2), 111-116. 
Letourneau, E.J., Brown, D.S., Fang, X., Hassan, A. and Mercy, J.A. (2018). The economic burden of child sexual abuse in the United States, Child Abuse \& Neglect, 79, 413-422.

Levine-Clark, M. (2010). From 'relief' to 'justice and protection': the maintenance of deserted wives, British masculinity and imperial citizenship, 1870-1920. Gender and History, 22, 302-321.

Lewis, J. (1995). The Voluntary Sector, the State and Social Work in Britain: The COS/Family Welfare Association since 1869, Aldershot: Edward Elgar.

Loopstra, R. (2015). Austerity, sanctions and the rise of food banks in the UK, BMJ, 350(2).

Melling, J., Adair, R. and Forsythe, B. (1997). A proper lunatic for two years': Pauper lunatic children in Victorian and Edwardian England, Child Admissions to the Devon County Asylum 1845-1914, Journal of Social History, 31(2), 371-394.

Morrison, J. (2016). Familiar strangers, juvenile panics and the British press: the decline of social trust. London: Palgrave Macmillan.

Morton, S. (2014). Wisdom, Justice, Charity: Canadian Social Welfare Through the Life of Jane B. Wisdom 1884-1975. Toronto: University of Toronto Press.

NSPCC (2016). Children in care Emotional wellbeing and mental health [Online]. Available at: https://www.nspcc.org.uk/preventing-abuse/child-protection-system/children-incare/emotional-wellbeing-of-children-in-care/ .

Pilgrim, D. (2014). Some implications of critical realism for mental health research, Social Theory \& Health, Vol. 12(1), 1-12.

Polat, B. (2016). Before attachment theory: separation research at the Tavistock clinic, 19481956, Journal of the History of Behavioral Sciences, 53(1), 48-70.

Powell, R. (2008). Understanding the Stigmatization of Gypsies: Power and the Dialectics of (Dis)identification, Houing, Theory and Society, 25(2),87-109.

Rey, J. M., Assumpção, F. B., Bernad, C. A., Çuhadaroğlu, F. C., Evans, B., Fung, D., Harper, G., Loidreau, L., Ono. Y., Pūras, D., Remschmidt, H., Robertson, B., Rusakoskaya, O. A. and Schleimer, K. (2015). History of child and adolescent psychiatry, In Rey JM (ed), IACAPAP e-Textbook of Child and Adolescent Mental Health, (1-67), Geneva: International Association for Child and Adolescent Psychiatry and Allied Professions.

Roberts, M.L.M. and Schiavenato, M. (2017). Othering in the Nursing Context: A Concept Analysis, Nursing Open, 4, 174-181.

Saka-Helmhout, A. (2018). Critical Realism and International Comparative Case Research, In: Edwards, P.K., O'Mahoney, J. and Vincent, S. (Eds), Studying Organizations Using Critical Realism, (185-204), Oxford: Oxford University Press.

Sales, R. (2002). The deserving and the undeserving? Refugees, asylum seekers and welfare in Britain. Critical Social Policy, 22(3), 456-478. 
Sayer A. (2000), Realism and Social Science, London:Sage.

Sohasky, K.E. (2015). Safeguarding the interests of the State from defective delinquent girls, Journal of the History of Behavioral Sciences, 52(1), 20-40.

Steffel, M., William, E.F. and Perrmann-Graham, J. (2016). Passing the buck: Delegating choices to others to avoid responsibility and blame, Organizational Behavior and Human Decision Processes, 135, 32-44.

Stein, M. (2006). Research Review: Young people leaving care, Child and Family Social Work, $11,273-279$.

Stewart, J. (2011). "The Dangerous Age of Childhood": Child Guidance and the "Normal" Child in Great Britain, 1920-1950, Pedagogica Historica, 47,785-803.

Tasca, C., Rapetti, M., Carta, M.G. and Fadda, B. (2012). Women and Hysteria in the History of Mental Health, Clinical Practice \& Epidemiology in Mental Health, 8, 110-119.

Thane, P. (2012). The 'Big Society' and the 'Big State': creative tension or crowding out? Twentieth Century British History, 23, 408-429.

Turpell-Lafond, M.E. (2014). Lost in the Shadows: How a Lack of Help meant a Loss of Hope for one First Nations Girl. Investigative Report Representative for Children and Youth, https://rcybc.ca/sites/default/files/documents/pdf/reports publications/rcy lost-in-theshadows forweb $17 \mathrm{feb}$.pdf.

Vaismoradi, M., Turunen, H. and Bondas, T. (2013). Content analysis and thematic analysis: Implications for conducting a qualitative descriptive study, Nursing \& Health Sciences, 15, 398-405.

Ward, H. (1990). The charitable relationship: parents, children and the Waifs and Strays Society, University of Bristol. [Online] Available at: https://researchinformation.bristol.ac.uk/files/34489504/292443.pdf

Whelan, R. (2001). Helping the Poor. Friendly visiting, dole charities and dole queues. London: Civitas:Institute for the Study of Civil Society.

Zehr, H. (2014). The Little Book of Restorative Justice, New York: Skyhorse Publishing.

\section{Appendix 1}

Table 3: Examples of Institutional, Social Policy/Social Work and Psychology/Psychiatry Factors

\begin{tabular}{|l|l|l|l|}
\hline & Institutions/Services & $\begin{array}{l}\text { Social Policy/Social } \\
\text { work }\end{array}$ & Psychology/Psychiatry \\
\hline $\begin{array}{l}\text { Data set 1: Children's } \\
\text { Society (Waifs and }\end{array}$ & $\begin{array}{l}\text { Industrial Schools (caring } \\
\text { for neglected children); } \\
1857-1933 .\end{array}$ & $\begin{array}{l}\text { Goschen (president of } \\
\text { the Poor Law Board) } \\
\text { slashes Poor Law }\end{array}$ & $\begin{array}{l}\text { Growing understanding of } \\
\text { the multiple factors } \\
\text { involved in the }\end{array}$ \\
\hline
\end{tabular}




\begin{tabular}{|c|c|c|c|}
\hline $\begin{array}{l}\text { Strays Society); } 1881- \\
1918 \text { timescale }\end{array}$ & $\begin{array}{l}\text { Waifs \& Strays Society } \\
\text { established in } 1881 . \\
\text { Asylums (no age limit); } \\
\text { no specialist children's } \\
\text { services }\end{array}$ & $\begin{array}{l}\text { spending in } 1869 ; \\
\text { establishment of the } \\
\text { Charity Organisation } \\
\text { Society, system of } \\
\text { personal social work. } \\
\text { NSPCC (National } \\
\text { Society for the } \\
\text { Prevention of Cruelty to } \\
\text { Children), } 1884 \\
\text { The Prevention of } \\
\text { Cruelty to and } \\
\text { Protection of Children } \\
\text { Act, or 'Children's } \\
\text { Charter', 1889 }\end{array}$ & $\begin{array}{l}\text { development of childhood } \\
\text { psychiatric disorders, } \\
\text { although the emphasis } \\
\text { was on heredity (e.g. } \\
\text { Maudsley, 1895). }\end{array}$ \\
\hline $\begin{array}{l}\text { Data set 2: Young care } \\
\text { leavers and } \\
\text { safeguarding } \\
\text { practitioners; 2015- } \\
2017 \text { timescale }\end{array}$ & $\begin{array}{l}\text { Charities, delivering } \\
\text { services for children in } \\
\text { care and young care } \\
\text { leavers. } \\
\text { Local authority } \\
\text { responsibility to provide } \\
\text { services for care leavers } \\
\text { (e.g. health and } \\
\text { wellbeing). } \\
\text { 'Staying put } \\
\text { arrangement'; supporting } \\
\text { young people to continue } \\
\text { to live with their former } \\
\text { foster carers once they } \\
\text { turn } 18 \text { (Children and } \\
\text { Families Act, 2014); }\end{array}$ & $\begin{array}{l}\text { Working together to } \\
\text { Safeguard Children } \\
\text { legislation (2015); } \\
\text { changes regarding } \\
\text { allegations of abuse, } \\
\text { serious incidents and } \\
\text { definition of serious } \\
\text { harm during serious } \\
\text { case reviews. } \\
\text { Children and Social } \\
\text { Work Act 2017 } \\
\text { Council spending on } \\
\text { early intervention } \\
\text { services designed to } \\
\text { spot signs of abuse and } \\
\text { neglect are cut by } 40 \% \\
\text { between 2010/11 and } \\
\text { 2014/15. } \\
\text { Cuts to Children's } \\
\text { Services (between } \\
2010 / 11-2014 / 15) \text {; cuts } \\
\text { to services in the South } \\
\text { by almost a quarter } \\
\text { (23\%). }\end{array}$ & $\begin{array}{l}\text { Transition from CAMHS } \\
\text { (Child and Adolescent } \\
\text { Mental Health Services) } \\
\text { to Adult Mental Health } \\
\text { Services. }\end{array}$ \\
\hline
\end{tabular}

Sources: Action for Children, NCB, and The Children's Society, 2017; DfE, 2015; Gingell, 2001; Hacking, 1991; Higginbotham, 2017;Legislation.gov.uk; Melling et al. 1997; NSPCC, 2016; Rey et al,. 2015; Ward, 1990; 